\title{
NEWS IN BRIEF
}

\section{India's Polio Policy for Travelers}

The war against polio in India was not won easily, and we dare not lest on our laurels. One way the wily virus can stage a comeback is to piggyback on travelers from countries where polio still exists. The Ministry of Health laid out new guidelines for travelers to and from polio endemic countries. All resident nationals of the currently seven polio infected countries are required to receive a dose of oral polio vaccine (OPV), regardless of age and vaccination status, at least four weeks prior to departure to India. All Indians travelling to these countries will also have to get a dose of the oral vaccine. The visitor will require to repeat vaccination if he/she travels again after one year of the last vaccine.

For those who consider this yet another beaurocratic inconvenience, it would do well to remember that between 2003 and 2006 the virus made a re-entry into twenty-four countries who had been previously declared polio free. It cost $\$ 450$ million to get the situation under control again. More recently, polio from Pakistan resurfaced in the Middle East.

The countries on the red list are: Afghanistan, Ethiopia, Kenya, Nigeria, Pakistan, Somalia, and Syria. It has been estimated that 234000 travelers visit India annually from these seven countries, and 346000 Indians travel to these countries. Vaccinating them all will be a small price to pay in the bigger picture of remaining polio-free. (The Lancet 2014;383:1632)

\section{The Post Antibiotic Era}

The WHO's recent global surveillance report - drawn from 114 countries - on antibiotic resistance warns that we are headed into 'the post-antibiotic era' where once again human beings will fall prey to simple infections and antibiotics will fail to work. How many realize that it is more than 27 years since a new class of antibiotics was discovered! In the WHO report, resistance patterns in 6 common bacteria, including Klebsiella, E. coli, Gonococcus and Methicillin-resistant Staph. aureus were studied. More than $50 \%$ of the countries reported more than $50 \%$ resistance to first line antibiotics. More than $95 \%$ of Indians and Pakistanis carry microbes resistant to beta lactams and carbapenems. In Nigeria, $88 \%$ of staphylococci are resistant to methicillin. Overuse of antibiotics, excessive use of antibiotics in animal husbandry and lack of government monitoring and restriction of antibiotic usage have all added their little bit to build up this gargantuan problem. This is a wakeup call to the global community which must not be ignored.

The Indian Medical Association has launched a nationwide program to educate doctors on rational use of antibiotics which includes avoidance of over prescription by doctors and selfmedication by patients. Indian Academy of Pediatrics is also rightly working in this direction. (http://www.who.int/ mediacentre/news/releases/2014/amr-report/en/; Nature 6 May 2014; The Hindu 15 April 2014)

\section{Air Quality in Indian Cities}

New Delhi now has the dubious distinction of being a city with the worst air quality in the world. WHO's recent global report on air quality in 1600 cities has calculated it based on the annual mean concentration of particulate matter less than 10 microns (PM10) and particulate matter less than 2.5 microns (PM2.5). That 13 of 20 of the world's most polluted cities are in India is a measure of the apathy and lack of vision in India's unbridled urban explosion. Patna, Gwalior and Raipur take the top three spots after New Delhi. In contrast, Beijing which has often been dubbed "Greyjing" due to its omnipresent smog, has a PM2.5 of 56 and stands at 77 th position. India has been quick to contradict these findings. Gufran Beig, Chief Project Officer at the Indian Institute of Tropical Meteorology says that New Delhi has better air quality than Beijing, especially in summer and the monsoon. As per the WHO guidelines, the recommended annual limit of PM10 is $20 \mu \mathrm{g} / \mathrm{m}^{3}$ (micrograms per cubic metre of air) and for $\mathrm{PM} 2.5$ it is $10 \mu \mathrm{g} / \mathrm{m}^{3}$. Unfortunately not even a single Indian city conforms to these standards. In stark contrast to Indian cities, London has a PM 2.5 of 16. It is not necessary that the growth in a city should parallel worsening air quality. Cities have actually shown progressive improvements in air quality like Copenhagen which has actively encouraged the use of bicycles and walkways. (http://www.who.int/mediacentre/news/releases/2014/airquality/en/; The Economic Times 8 May 2014).

Gouri Rao PASSI gouripassi@hotmail.com 